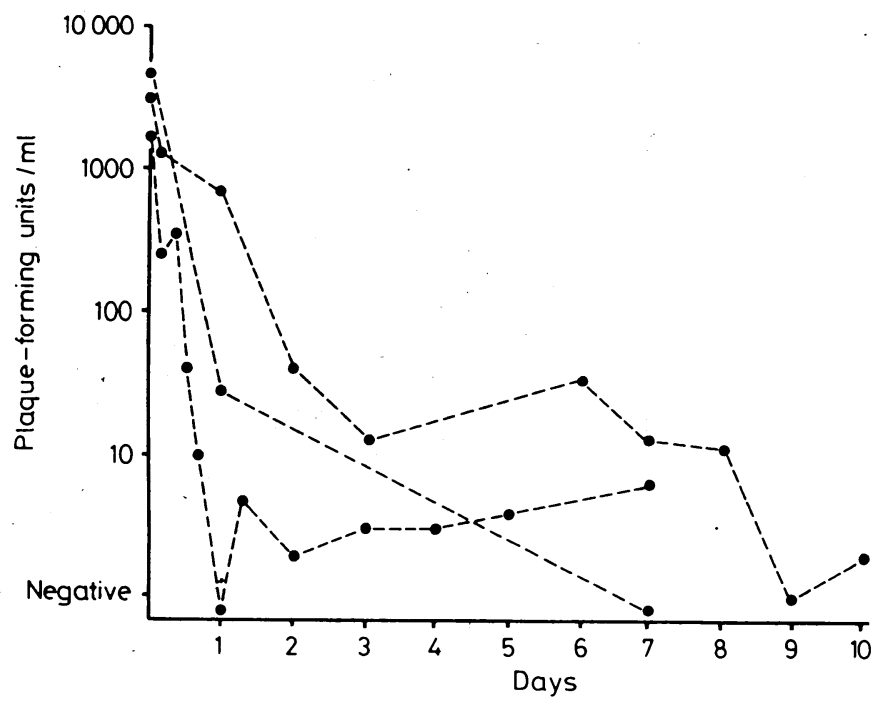

Effect of storage at $-20^{\circ} \mathrm{C}$ on survival of cytomegalovirus in three specimens obtained at weekly intervals from a milk donor.

\section{Discussion}

By using a sensitive plaque method to determine excretion of cytomegalovirus in human milk we found that both the number of excretors and the amount of virus in milk may be consider- ably higher than previously reported. ${ }^{4} 5$ This confirms the importance of breast-milk' as a source of transmission of cytomegalovirus infection. The course of infection in infants infected by their mother's milk is usually subclinical, probably owing to antibodies acquired transplacentally. Cytomegalovirus may constitute a hazard, however, when milk is collected and given raw to preterm and mature seronegative babies.

The risk of using raw milk is reduced considerably by keeping the milk at $-20^{\circ} \mathrm{C}$ for at least three days, but high-titred milk may, however, still contain a slight residue of cytomegalovirus of certain infective potential. Pasteurisation at $63^{\circ} \mathrm{C}$ for eight minutes will kill cytomegalovirus in milk.

This study was supported by grant No 12-3087 from Statens Laegevidenskabelige Forskningsråd.

\section{References}

${ }^{1}$ Anonymous. Sterilisation of human milk. (Editorial.) Lancet 1979;i:913.

${ }^{2}$ Björkstén B, Burman LG, de Chateau P, Frederikzon B, Gothefors L, Hernell $\mathrm{O}$. Collecting and banking human milk: to heat or not to heat? Br Med F 1980;281:765-9.

${ }^{3}$ Andersen $\mathrm{HK}$, Brostrøm K, Hansen $\mathrm{KB}$, et al. A prospective study on the incidence and significance of congenital cytomegalovirus infection. Acta Paediatr Scand 1979;68:329-36.

${ }^{4}$ Hayes K, Danks DM, Gibas H, Jack J. Cytomegalovirus in human milk. $N$ Engl f Med 1972;297:177-8.

5 Stagno S, Reynolds DW, Pass RF, Alford CA. Breast milk and the risk of cytomegalovirus infection. $N$ Engl f Med 1980;302:1073-6.

(Accepted 13 August 1982)

\title{
Enkephalin inhibits relaxation of the lower oesophageal sphincter
}

\author{
J M HOWARD, M R BELSHEIM, S N SULLIVAN
}

\begin{abstract}
Five healthy volunteers were studied for the effect on oesophageal motility of a single subcutaneous injection of a synthetic analogue of enkephalin as compared with an injection of an equivalent volume $(0.5 \mathrm{ml})$ of saline. The injections were given at random on separate days, and each was followed after 40 minutes by $2 \mathrm{mg}$ naloxone given intravenously. Pressures were measured by manometry after dry and wet $(5 \mathrm{ml})$ swallows at one-minute intervals, and traces were coded and analysed "blind."

Twenty-five minutes after the injection of enkephalin the percentage relaxation of the lower oesophageal sphincter pressure was significantly less $(p<0.005)$ than at the same time after saline. Within two minutes after intravenous naloxone this effect had disappeared completely. Enkephalin had no noticeable effect on pressure of the sphincter or on amplitude and duration of oesophageal peristalsis.
\end{abstract}

The mechanism of action of enkephalin in selectively

Department of Medicine, Colborne II, Victoria Hospital, London, Ontario, Canada

J M HOWARD, MD, resident in gastroenterology

M R BELSHEIM, MD, FRCP(C), consultant in gastroenterology

S N SULLIVAN, MRCP, FRCP(C), consultant in gastroenterology inhibiting relaxation of the lower oesophageal sphincter remains to be determined. That naloxone rapidly reversed the inhibition may be relevant in achalasia and warrants further study.

\section{Introduction}

Opiate receptors and enkephalin-containing neurons occur throughout the gastrointestinal tract. In the oesophagus these neurons lie in the muscularis propria and muscularis mucosae. Other enkephalinergic neurons are found in the vagus nerve. The function of these neurons is unknown. We have studied the effects of a long-acting synthetic enkephalin analogue (Sandoz FK33-824; DAMME) on the motility of the oesophagus.

\section{Methods and results}

Five healthy fasting volunteers were studied on two occasions. Manometry was performed with a seven-lumen catheter perfused by a pneumohydraulic capillary infusion pump. Once the lower oesophageal sphincter had been identified the catheter was secured and continuous recordings made in five locations (intragastric, lower oesophageal sphincter, and 5,10 , and $15 \mathrm{~cm}$ proximal to the lower oesophageal sphincter). Peristalsis was initiated by alternating dry and wet $(5 \mathrm{ml})$ swallows at one-minute intervals. After a 10-minute basal recording the subjects randomly received on separate days either a subcutaneous 
injection of $0.5 \mathrm{mg}$ of the enkephalin analogue or an equivalent volume of saline. Forty minutes later $2 \mathrm{mg}$ naloxone was given intravenously and the recording continued for a further 20 minutes. The traces were coded and analysed blindly. Each manometric record was divided into 10-minute segments, and mean peristaltic amplitude and duration and lower oesophageal sphincter pressure and percentage relaxation in each segment were compared within and between studies by paired Student's $t$ test. There were no significant differences between wet and dry swallows and the results were therefore pooled.

The enkephalin analogue inhibited relaxation of the lower oesophageal sphincter in response to both wet and dry swallows (figure).

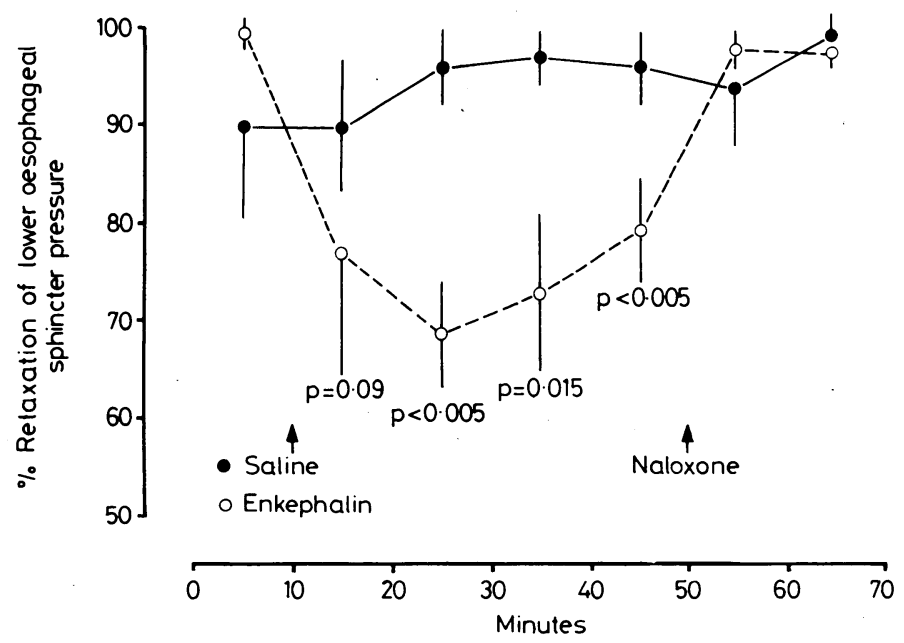

Percentage decrease in relaxation of lower oesophageal sphincter pressure after wet or dry swallows. Reversal by naloxone of effect of enkephalin analogue complete within two minutes of injection.

This effect was completely abolished within two minutes after intravenous injection of naloxone. The enkephalin analogue did not significantly affect the lower oesophageal sphincter pressure or oesophageal peristaltic amplitude and duration. After subcutaneous injection of saline there were no significant changes in motility, and the administration of naloxone did not affect any index of oesophageal motility.

\section{Discussion}

Studies of the effects of opiates on the oesophagus have been few and contradictory. In 1937 Krueger reviewed the action of morphine on the oesophagus, noting that in cats morphine "interfered with passage through the cardia in either direction."' Schmidt in 1939 reported that morphine caused "rather severe, prolonged relaxation of the distal portion of the [human] oesophagus." ${ }^{2}$ Hall and co-workers reported in 1975 that morphine and meperidine (pethidine) caused a reduction in lower oesophageal sphincter pressure in man and rhesus monkeys. ${ }^{3}$

Renewed interest in the effects of opiates on oesophageal function followed the identification of opiate receptors and the detection of opiate peptides in the vagus nerve and oesophageal myenteric plexus. In vitro, morphine, codeine, and metenkephalin cause contraction of the lower oesophageal sphincter of opossums. ${ }^{4}$ In contrast, in cats met-enkephalin inhibits electrically stimulated contraction of lower oesophageal muscle strips. ${ }^{5}$ Intra-arterial injections of met-enkephalin and leuenkephalin increase lower oesophageal sphincter pressure in opossums, while injection of the larger opiate peptides $\alpha$-endorphin and $\beta$-endorphin decrease pressure ${ }^{6}$ Clearly, variable if not opposite effects of opiates on oesophageal function have been described depending on the species and study protocol used.

In none of the above studies did the authors comment on the effect of opiates on relaxation of the lower oesophageal sphincter. We were therefore surprised that the enkephalin analogue inhibited relaxation of the sphincter while having no effect on all other indices of oesophageal motility. We know of no other class of substances which selectively inhibit relaxation of the sphincter.

The mechanism of inhibition of relaxation of the lower oesophageal sphincter is not clear. Opiates do not affect the basal plasma concentrations of any gastrointestinal peptide known to influence oesophageal motility, but they do inhibit the release of several neurotransmitters, including acetylcholine, noradrenaline, dopamine, and substance $P$. If relaxation of the lower oesophageal sphincter is mediated by neurons containing these neurotransmitters then inhibition of neurotransmitter release by opiates would prevent the normal relaxation of the sphincter in response to swallowing. Naloxone alone had no effect on oesophageal motility. If the large dose of naloxone used was enough to block the effects of endogenous opiates it is unlikely that tonic opiate innervation of the lower oesophageal sphincter is of major physiological importance in the function of the sphincter. Naloxone, however, rapidly reversed the inhibition of relaxation induced by the enkephalin analogue, and it would therefore be interesting to study the effect of naloxone in patients with achalasia, in whom failure of relaxation of the lower oesophageal sphincter is the primary disorder.

This study was supported by a grant from the Ontario Ministry of Health.

\section{References}

1 Krueger $\mathrm{H}$. The action of morphine on the digestive tract. Physiol Rev 1937;17:619-45.

2 Schmidt HW. Diffuse spasm of the lower half of the esophagus. Am $\mathcal{F}$ Dig Dis $1939 ; 6: 693-700$.

${ }^{3}$ Hall AW, Moossa AR, Clark J, et al. The effects of premedication drugs on the lower oesophageal high pressure zone and reflux status of rhesus monkeys and man. Gut 1975;16:347-52.

4 McCallum RW, Dodds J, Osborne HP, Biancani P. In vitro effect of enkephalin and other opiates on opossum lower esophageal sphincter (LES). Gastroenterology $1979 ; 76: 1198$.

5 Uddman R, Aluments J, Hakanson R, et al. Peptidergic (enkephalin) innervation of the mammalian esophagus. Gastroenterology $1980 ; 78$ : 732-7.

${ }^{6}$ Rattan S, Goyal RK. Effect of morphine and endogenous opiates on the opossum lower esophageal sphincter. Gastroenterology 1980;78:1241.

(Accepted 11 August 1982)

ONE HUNDRED YEARS AGO A gentleman, discharged last year from the Barnwood Lunatic Asylum at Gloucester, has complained to the Commissioners in Lunacy that all his letters, written when in a state of insanity, were duly forwarded to their destination. $\mathrm{He}$ is indignant that epistles bearing evident traces of mental disease, which he addressed to numerous friends, were punctually transmitted to them, and that he was thus, as it were, permitted to make a fool of himself in public. The complaint has hitherto been that letters are intercepted in asylums; and we can well believe that those who are in charge of the insane are sorely puzzled what to do with the correspondence of their patients, as whether they forward or detain letters they are equally liable to give offence. (British Medical fournal, 1882.)

ONE HUNDRED YEARS AGO Miss Joanna Hastings of Malvern, the eldest sister of Sir Charles Hastings, the founder of the British Medical Association, completed the hundredth year of her age on Tuesday, March 14th. Although somewhat infirm in body, her mental faculties are, it is said, still vigorous, and her health is good. On her birthday, she received numerous congratulations, and dined with a large number of members of the Hastings family at the residence of her nephew, Mr George Hastings, MP, of Barnard's Green, where she responded in well-chosen and vigorous words to the toast of her health. The father of Sir Charles Hastings, the Rev James Hastings of Martley, was above a century old at the time of his death in 1855. (British Medical fournal, 1882.) . . 